\author{
B.Kh. Mussabayeva ${ }^{1}$, K.B. Murzagulova ${ }^{1}$, V.A. Izumrudov ${ }^{2}$, \\ M.E. Kim ${ }^{3}$, R.T. Dinzhumanova ${ }^{1}$ \\ ${ }^{I}$ Shakarim State University of Semey, Kazakhstan; \\ ${ }^{2}$ M.V. Lomonosov Moscow State University, Russia; \\ ${ }^{3}$ "Pharmtan» Company, Semey, Kazakhstan \\ (E-mail: binur.mussabayeva@mail.ru)
}

\title{
Polyelectrolytic multilayers as drug delivery system
}

\begin{abstract}
This article is devoted to preparation of polyelectrolytic microcapsules of two antitubercular drugs (ATDs) as the new drug delivery system (DDS). Co-encapsulation of oral antitubercular drugs pyrazinamide and moxifloxcin by polyelectrolytic multilayers is carried out for the first time. At first by ionotropic gelation method co-encapsulation of drugs to a polymeric matrix carried out. As a matrix biopolymers gellan and sodium alginate were used. The co-encapsulation efficiency was determined using UV-spectroscopy method as it is specified in the State pharmacopeia of the Republic of Kazakhstan. Then by the method of fiber adsorption (LbL-technique - Layer by layer deposition) on microcapsules sequentially coated a cationic polyelectrolyte chitosan and an anionic polyelectrolyte eudragit S100. The charge of each layer was determined by zeta-potential measurement. Microcapsules about 3,5 and 10 bilayers of polyelectrolytes are prepared. The structure of microcapsules was studied by method of the scanning submicroscopy. In vitro drug release studies carried out at values $\mathrm{pH}$, modeling various sites of digestive tract. As a result of a research it is shown that microcapsules possess the prolonged action. With increase in number of bilayers extent of prolongation of drugs increases. It is enough 5 bilayers of polyelectrolytes to achieve the 24th hour prolongation of drugs.
\end{abstract}

Keywords: antitubercular drugs, microcapsule, biopolymers, polyelectrolytic multilayers, controlled release.

\section{Introduction}

For the treatment of drug-resistant forms of tuberculosis, patients are forced to take 20 tablets of six types of drugs per day. It is interfaced by heavy side effects. Accordingly, any attempts to enhance drugresistant tuberculosis treatment in order to it's endure by patients are actual and socially-implicated. Therefore, scientists conduct various researches on the dosage optimization, prolonged action and enhanced bioavailability of antitubercular drugs [1]. For this purpose various drug delivery systems (DDS) have been developed: microparticles, nanoparticles, liposomes, polymeric composites, the hollow and filled capsules. In the literature there is a lot of works devoted to the use of biopolymers as DDS [2, 3]. However, there are very few literary data on encapsulation of antitubercular drugs by polyelectrolytic multilayers. For example, rifampicin encapsulated into chitosan-dextran sulfate hollow microcapsules. Rifampicin released from these microcapsules within over 72 hours at $\mathrm{pH}=1.2$ and $\mathrm{pH}=7.4$ [4]. One of the urgent solutions of the problem of the dosage optimization is the development of new DDS for the preparation of combined and prolonged forms of ATDs.

The goals of this work are co-encapsulation of two antitubercular drugs - pyrazinamide and moxifloxacin in the biopolymer coated with polyelectrolytic multilayers, and evaluation of drug release at values $\mathrm{pH}$, modeling various sites of a gastrointestinal tract (GIT).

\section{Materials and methods}

The biopolymers low-acetylated gellan (China producted) and sodium alginate (Sigma-Aldrich) were used as the containers for capsules. For preparation of multilayers the cationic polyelectrolyte chitosan (Chit) water-soluble, $\geq 8000 \mathrm{Da}$ (Bioprogress, Moscow) and anionic polyelectrolyte Eudragit S100 (Eud) (SigmaAldrich) were chosen.

Substances of antitubercular drugs pyrazinamide (Pz), (Shanghai International Pharmaceutical Co), a moxifloxacin hydrochloride (Mfx) (Pavlodar Pharmaceutical Plant, Kazakhstan) were used.

Drug containing microcapsules were prepared by ionotropic gelation method [5,6]. The co-encapsulation efficiency was determined using the methods given in Pharmacopoeia: the quantity of pyrazinamide and moxifloxacin were determined on the spectrophotometer (Specord 210, Germany) at $268 \mathrm{~nm}$ and $295 \mathrm{~nm}$ accordingly [7]. 
The coating of microcapsules by polyelectrolytic multilayers was carried out by LbL-technique (Layer by layer deposition), consistently immersing them in water solution of a chitosan and in Eudragit S100 solution in sodium chloride. After immersion in each polyelectrolyte the microcapsules were twice washed with distilled water. This procedure was repeated 3,5 or 10 times. Thus, 3, 5 or 10 bilayers of oppositely charged polyelectrolytes have been formed.

Dzeta-potential of each polyelectrolytic layer was measured by dynamic light scattering method on Malvern Zetasizer Nano ZS90 (Great Britain).

The surface morphology of the microcapsules was studied by scanning electronic microscopy on a lowvacuum raster electronic microscope of «JEOL» of JSM-6390 LV (Japan).

In vitro drug release studies carried out according to Pharmacopoeia requirements [7], using the dissolution apparatus (Erweka, Germany) at a temperature $(37 \pm 0.5){ }^{\circ} \mathrm{C}$ and the rotation speed $100 \mathrm{rpm}$. The tests were performed at gastric $\mathrm{pH}(0.1 \mathrm{~N} \mathrm{HCl}, \mathrm{pH}=1.2)$ and intestinal $\mathrm{pH}$ (phosphate buffer, $\mathrm{pH}=7.4)$. Concentrations of the drugs were determined using UV-Visible spectrophotometric method at 268 and $295 \mathrm{~nm}$. All quantitative analyses were repeated 3 times.

\section{Results and discussion}

Drug containing spherical microcapsules of size around of 1,5-2,0 $\mathrm{mm}$ were prepared. Microcapsules were kept within $10 \mathrm{~min}$ in calcium salt solution, then passed through a sieve and washed twice in distilled water and dried on air at room temperature. The solution was used for the determination of co-encapsulation efficiency.

SEM microphotographs of microcapsules same as gellan-isoniazide microcapsule with 5 bilayers Chit/DS [6], and also the border between the microcapsule and polyelectrolytic layers is visible (see Fig.).

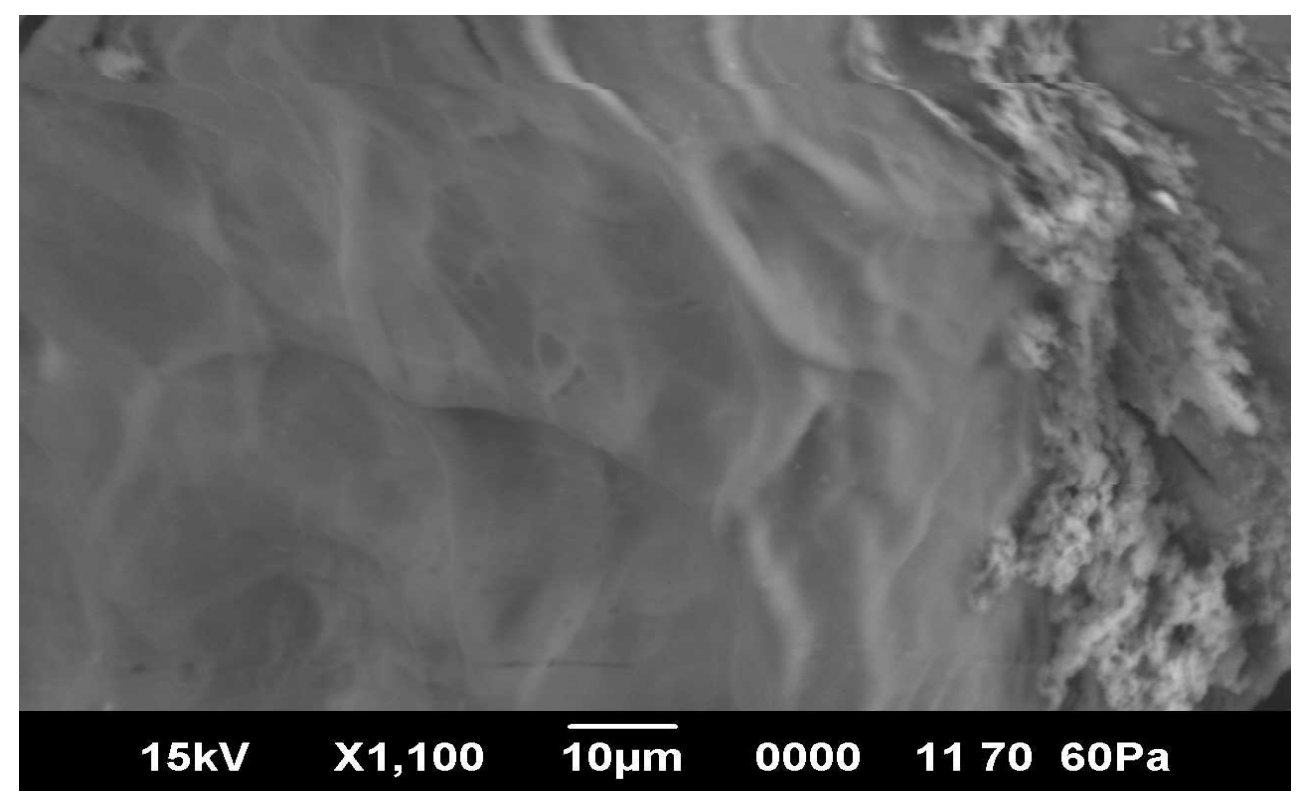

Figure. SEM microphotograph of microcapsule $3 \%$ gellan/Pz/Mfx +3 bilayers Chit/Eud

Results of co-encapsulation efficiency determination are given in Table 1.

\section{Co-encapsulation efficiency, \%}

\begin{tabular}{|l|c|c|}
\hline Microcapsule matrix & Pyrazinamide & Moxifloxacin \\
\hline $1 \%$ gellan & $27,5 \pm 1,3$ & $27,6 \pm 10,6$ \\
\hline $3 \%$ gellan & $39,9 \pm 4,2$ & $41,8 \pm 2,2$ \\
\hline $2 \%$ alginate & $26,5 \pm 3,1$ & $32,1 \pm 2,6$ \\
\hline $3 \%$ alginate & $28,0 \pm 2,1$ & $51,1 \pm 3,4$ \\
\hline
\end{tabular}


Apparently from table 1, generally co-encapsulation efficiency increases with the increase of biopolymer concentration. It is interesting that co-encapsulation efficiency of drugs is a bit higher, comparing to the efficiency of their separate encapsulation [6].

After covering by polyelectrolytes dzeta potential of microcapsules were measured. Microcapsules possess a positive or negative charge after adsorption of chitosan and eudragit respectively (Table 2).

Table 2

\section{Results of dzeta-potential measurements}

\begin{tabular}{|l|c|c|}
\hline Composition of microcapsule & $3 \%$ gellan/Pz/Mfx + Chit & $3 \%$ gellan/Pz/Mfx + Chit/Eud \\
\hline Dzeta-potential, $\mathrm{mV}$ & $19 \pm 2$ & $-16 \pm 2$ \\
\hline
\end{tabular}

In vitro drug release studies have shown, that in acidic media at $\mathrm{pH}=1.2$ (corresponds to the gastric) capsules did not dissolve within a day.

At $\mathrm{pH}=7.4$ (corresponds to intestines) microcapsules gradually dissolved (Tables 3 and 4).

T a b le 3

\section{Drug release from gellan capsules at $\mathrm{pH}=7.4, \%$}

\begin{tabular}{|c|c|c|c|}
\hline \multirow{2}{*}{ Composition of microcapsule } & \multirow{2}{*}{ Release time, hour } & \multicolumn{2}{|c|}{ Extent of release, \% } \\
\cline { 2 - 4 } & & Pyrazinamide & Moxifloxacin \\
\hline \multirow{2}{*}{$\begin{array}{c}3 \% \text { gellan/Pz/Mfx } \\
\text { (without multilayers) }\end{array}$} & 4 & $34,6 \pm 4,8$ & $34,7 \pm 4,5$ \\
\cline { 2 - 4 } & 12 & $54,8 \pm 4,5$ & $89,4 \pm 1,1$ \\
\hline \multirow{2}{*}{$\begin{array}{c}\text { 3 gellan/Pz/Mfx } \\
3 \text { bilayers Chit/Eud }\end{array}$} & 6 & $81,2 \pm 2,3$ & $27,0 \pm 1,2$ \\
\cline { 2 - 4 } & 12 & $25,9 \pm 0,9$ & $49,5 \pm 0,6$ \\
\hline \multirow{2}{*}{$3 \%$ gellan/Pz/Mfx +} \\
5 bilayers Chit/Eud & 18 & $88,6 \pm 1,9$ & $26,4 \pm 7,9$ \\
\cline { 2 - 4 } & 12 & $26,3 \pm 1,9$ & $46,5 \pm 1,3$ \\
\hline \multirow{2}{*}{$\begin{array}{c}\text { 3 gellan/Pz/Mfx }+ \\
10 \text { bilayers Chit/Eud }\end{array}$} & 24 & $45,8 \pm 0,7$ & $75,2 \pm 1,9$ \\
\cline { 2 - 4 } & 12 & $75,6 \pm 0,5$ & - \\
\hline
\end{tabular}

T a b l e 4

Drug release from alginate capsules at $\mathrm{pH}=7.4, \%$

\begin{tabular}{|c|c|c|c|}
\hline \multirow{2}{*}{ Composition of microcapsule } & \multirow{2}{*}{ Release time, hour } & \multicolumn{2}{|c|}{ Extent of release, \% } \\
\cline { 2 - 3 } & & $31,8 \pm 3,8$ & Moxifloxacin \\
\hline \multirow{2}{*}{$\begin{array}{c}3 \% \text { alginate/Pz/Mfx } \\
\text { (without multilayers) }\end{array}$} & 8 & $52,1 \pm 3,9$ & $32,9 \pm 3,5$ \\
\cline { 2 - 4 } & 12 & $79,8 \pm 3,6$ & $81,2 \pm 2,5$ \\
\hline \multirow{2}{*}{$3 \%$ alginate/Pz/Mfx } \\
3 bilayers Chit/Eud & 6 & $28,9 \pm 1,8$ & $28,5 \pm 2,5$ \\
\cline { 2 - 4 } & 12 & $47,9 \pm 2,4$ & $48,9 \pm 1,0$ \\
\cline { 2 - 4 } $3 \%$ alginate/Pz/Mfx & 18 & $80,0 \pm 2,3$ & $27,6 \pm 4,1$ \\
\cline { 2 - 4 } 5 bilayers Chit/Eud & 12 & $28,3 \pm 3,8$ & $47,8 \pm 2,3$ \\
\cline { 2 - 4 } & 18 & $46,5 \pm 0,9$ & $75,9 \pm 2,6$ \\
\hline \multirow{2}{*}{$3 \%$ alginate/Pz/Mfx +} & 24 & $76,6 \pm 1,4$ & - \\
\cline { 2 - 4 } 10 bilayers Chit/Eud & 12 & - & $11,9 \pm 2,8$ \\
\cline { 2 - 4 } & 18 & $10,9 \pm 2,7$ & - \\
\hline
\end{tabular}

Apparently from the table 3 and 4 the release (\%) of pyrazinamide and moxifloxacin from combined microcapsules without polyelectrolytic multilayers in 4 hours is about $30 \%$ of the active substance, in 8 hours - about $50 \%$, for 12 hours - about $80 \%$. Thus, the prolongation made 12 hours. 
In case of the microcapsules covered with 3 polyelectrolytic bilayers more prolonged release was observed: in 6 hours $30 \%$ of the active substance, in 12 hours $-50 \%$, in 18 hours $-80 \%$ are released. In this case prolongation made 18 hours, i.e. is 1,5 times longer, than without multilayers.

In case the covering made 5 bilayers the prolongation is higher: in 12 clocks released $30 \%$ of the active substance, in 18 hours $-50 \%$, in 24 hours $-80 \%$ are released. In this case prolongation made 24 hours. Capsules with 10 bilayers of polyelectrolytes began to dissolve after 20 hours, in 24 hours only about $10 \%$ of the active substance are released.

\title{
Conclusions
}

Thus, co-encapsulation of ATDs pyrazinamide and moxifloxacin by biopolymer and polyelectrolytic multilayers was carried out for the first time. Safe biodegradable and biocompatible polymers were used for co-encapsulation.

Co-encapsulation was performed in aqueous solutions at room temperature without using costly or special equipment, polyelectrolyte multilayers were coated using LbL-technique.

It is shown that polyelectrolytic co-encapsulation allows to prepare the prolonged form of the combined ATDs for oral use. It is enough to coat microcapsules with only 5 bilayers of polyelectrolytes for the achievement of 24 hour prolongation of drugs.

\section{Acknowledgements}

This study was performed with the financial support of the Ministry of Education and Science of the Republic of Kazakhstan, grant № 0794/ GF4.

\section{References}

1 WHO Global tuberculosis report (2016). - [ER]. Retrieved from http://apps.who.int/iris/bitstream/10665/250441/ 1/9789241565394-eng.pdf.

2 Muthu Mohamed J. Preparation and evaluation of alginate/chitosan particulate system for rifampicin release / J. Muthu Mohamed, S. Vetriselvan, N. Kishore Yadav, M.D. Raja, C. Senthil Kumar, M. Mohamed Raffick, et al. // International Journal of Pharmacy \& Therapeutics. - 2012. - Vol. 3, No. 2. - P. 215-220.

3 Sabitha P. Design and evaluation of controlled release chitosan-calcium alginate microcapsules of antitubercular drugs for oral use / P. Sabitha, Vijaya J. Ratna, K. Ravindra Reddy // Int. J. Chem. Technol. Res. — 2010. — No. 2. — P. 88-98.

4 Devi M.G. Studies on encapsulation of Rifampicin and its release from chitosan-dextran sulfate capsules / M.G. Devi, S. Dutta, A.T. Al Hinai, S. Feroz // Korean Journal of Chemical Engineering. — 2015. — Vol. 32, No. 1. — P. $118-124$.

5 Мусабаева Б.Х. Патент РК на полезную модель «Способ микрокапсулирования лекарственных препаратов». № 2055 / Б.Х. Мусабаева, К.Б. Мурзагулова, З.Ж. Арипжанова, Ж.С. Касымова, Л.К. Оразжанова // Бюлл. № 5 от 15.03.2017 г.

6 Mussabayeva B. Encapsulation of Antitubercular Drugs by Biopolymers and Polyelectrolyte Multilayers / B. Mussabayeva, K. Murzagulova, V. Izumrudov, D. Iminova, L. Orazzhanova, Zh. Kasymova, N. Kasenova // Res. J. of Pharm., Biol. and Chem. Sc. — 2016. - Vol. 7, No. 5. - P. 2951-2955.

7 Государственная Фармакопея Республики Казахстан: в 2 т. - Алматы: Жібек жолы, 2009. — Т. 2. — 804 с.

\section{Б.Х. Мұсабаева, К.Б. Мұрзағұлова, В.А. Изумрудов, М.Е. Ким, Р.Т. Дінжұманова}

\section{Полиэлектролитті мультқабаттар дәрілерді жеткізу жүйесі ретінде}

\begin{abstract}
Мақала жаңа дәрі-дәрмек жеткізу жүйесі ретінде екі туберкулезге қарсы препараттың полиэлектролитті микрокапсулаларын алуға арналды. Пероральді туберкулезге қарсы препараттар пиразинамид және моксифлоксацинді полиэлектролитті мультиқабаттармен біріктіре капсулдеу алғаш рет жүргізілді. Алдымен ионотропты гель түзу әдісімен препараттар полимерлік матрицаға капсулденді. Матрица ретінде геллан және натрий альгинаты биополимерлері пайдаланды. Препараттардың микрокапсулаға ену тиімділігі Қазақстан Республикасының Мемлекеттік фармакопеясында көрсетілгендей, УК-спектроскопия әдісімен анықталды. Содан кейін микрокапсулалар беті кезек қабаттармен адсорбциялау әдісімен (LbL техникасы — Layer by layer deposition) катиондық полиэлектролит хитозан және аниондық полиэлектролит эудрагитпен S100 қапталды. Әрбір қабаттың заряды дзета-потенциалын өлшеу арқылы анықталды. Полиэлектролиттердің 3, 5 және 10 қос қабатымен қапталған микрокапсулалар алынды. Микрокапсулалар құрылымы сканирлеуші электрондық микроскопия әдісімен зерттелді. Асқазан-ішек жолдарының әр түрлі бөліктерін модельдейтін $\mathrm{pH}$ мағыналарында препараттардың босап шығуы in vitro жағдайында зерттелді. Зерттеу нәтижесінде микрокапсулалардың ұзартылған әсері бар екені көрсетілді. Қос қабат сандары ұлғайған
\end{abstract}


сайын препараттардың әсерін ұзарту дәрежесі де артады. 5 полиэлектролитті қос қабатпен қаптағанда 24 сағаттық ұзартуға қолжеткізуге болады.

Кілm сөздер: туберкулезге қарсы препараттар, микрокапсула, биополимерлер, полиэлектролитті мультиқабаттар, бақыланатын босап шығу.

\title{
Б.Х. Мусабаева, К.Б. Мурзагулова, В.А. Изумрудов, М.Е. Ким, Р.Т. Динжуманова
}

\section{Полиэлектролитные мультислои как система доставки лекарств}

\begin{abstract}
Статья посвящена получению полиэлектролитных микрокапсул двух противотуберкулезных препаратов в качестве новой системы доставки лекарств. Впервые проведено совместное капсулирование пероральных противотуберкулезных препаратов пиразинамида и моксифлоксацина полиэлектролитными мультислоями. Сначала методом ионотропного гелеобразования проводилось капсулирование препаратов в полимерную матрицу. В качестве матрицы использованы биополимеры геллан и альгинат натрия. Эффективность включения препаратов в микрокапсулы определяли методом УФспектроскопии, как указано в Государственной фармокопее Республики Казахстан. После этого методом послойной адсорбции (техника LbL - Layer by layer deposition) на микрокапсулы последовательно наносились катионный полиэлектролит хитозан и анионный полиэлектролит эудрагит S100. Заряд каждого слоя определяли измерением дзета-потенциала. Получены микрокапсулы с 3, 5 и 10 бислоями полиэлектролитов. Структуру микрокапсул изучали методом сканирующей электронной микроскопии. Изучено высвобождение препаратов in vitro при значениях $\mathrm{pH}$, моделирующих различные участки желудочно-кишечного тракта. В результате исследования показано, что микрокапсулы обладают пролонгированным действием. С увеличением числа бислоев повышается степень пролонгации препаратов. Показано, что при нанесении 5 полиэлектролитных бислоев можно добиться 24-часовой пролонгации.
\end{abstract}

Ключевые слова: противотуберкулезные препараты, микрокапсула, биополимеры, полиэлектролитные мультислои, контролируемое высвобождение.

\section{References}

1 WHO Global tuberculosis report (2016). who.int/tb/publications. Retrieved from http://apps.who.int/iris/bitstream/ 10665/250441/1/9789241565394-eng.pdf.

2 Muthu Mohamed, J., Vetriselvan, S., Kishore Yadav, N., Raja, M.D., Senthil Kumar, C., \& Mohamed Raffick, M., et al. (2012). Preparation and evaluation of alginate/chitosan particulate system for rifampicin release. International Journal of Pharmacy \& Therapeutics, 3, 2, 215-220.

3 Sabitha, P., Vijaya, Ratna J., \& Ravindra, Reddy K. (2010). Design and evaluation of controlled release chitosan-calcium alginate microcapsules of antitubercular drugs for oral use. Int. J. Chem. Technol. Res., 2, 88-98.

4 Devi, M.G., Dutta, S., Al Hinai, A.T., \& Feroz, S. (2015). Studies on encapsulation of Rifampicin and its release from chitosan-dextran sulfate capsules. Korean Journal of Chemical Engineering, 32, 1, 118-124.

5 Mussabayeva, B.Kh., Murzagulova, K.B., Aripzhanova, Z.Zh., Orazzhanova, L.K., \& Kasymova, Zh.S. (2017). Sposob mikrokapsulirovaniia lekarstvennykh preparatov [A method of microencapsulating drugs]. Patent Respubliki Kazahstan na poleznuju model' [Patent for the useful model of the Republic of Kazakhstan]. No. 2055. Publ. 15.03.2017, Bull. No. 5 [in Russian].

6 Mussabayeva, B., Murzagulova, K., Izumrudov, V., Iminova, D., Orazzhanova, L., Kasymova, Zh., \& Kasenova, N. (2016). Encapsulation of Antitubercular Drugs by Biopolymers and Polyelectrolyte Multilayers. Res. J. of Pharm., Biol. and Chem. Sc., 7, 5, 2951-2955.

7 Gosudarstvennaia farmakopeia Respubliki Kazahstan [State Pharmacopeia of the Republic of Kazakhstan]. (2009). (Vols. 12, Vol. 2). Almaty: Zhibek zholy [in Russian]. 